\title{
PENGARUH SUHU, RASIO BAHAN BAKU TERHADAP PELARUT DAN KECEPATAN PENGADUKAN PADA PROSES FRAKSINASI TRIPALMITIN DARI FRAKSI PADAT MINYAK SAWIT
}

\author{
Fiqih Azis Pangestu ${ }^{1}$, Tri Yuni Hendrawati ${ }^{2}$, dan Wiwik Handayani ${ }^{3}$ \\ 1) 2) Jurusan Teknik Kimia, Fakultas Teknik, Universitas Muhammadiyah Jakarta, \\ Jl. Cempaka Putih Tengah 27 Jakarta Pusat 10510 \\ 3) Pusat Teknologi Agroindustri, Kedeputian Teknologi Agroindustri dan Bioteknologi, Badan \\ Pengkajian dan Penerapan Teknologi (BPPT) \\ Gedung 610 LAPTIAB, Kawasan PUSPIPTEK, Serpong, Tangerang Selatan 15314 \\ azispangestu16@gmail.com
}

\begin{abstract}
ABSTRAK
Minyak sawit merupakan minyak yang paling banyak diproduksi di Indonesia. Minyak sawit mempunyai dua jenis produk yaitu fraksi padat (Stearin) dan fraksi cair (Olein). Asam lemak pada minyak sawit dibedakan menjadi dua golongan yaitu asam lemak jenuh dan asam lemak tak jenuh. Penelitian ini bertujuan untuk memisahkan Tripalmitin dari fraksi padat minyak sawit melalui metode fraksinasi dengan pelarut organik. Variabel dalam penelitian ini menggunakan variasi rasio bahan baku / pelarut organik 1:10 (w/v) dan 1:12 (w/v) dengan suhu $2^{\circ} \mathrm{C}, 10^{\circ} \mathrm{C}, 20^{\circ} \mathrm{C}, 30^{\circ} \mathrm{C}, 40^{\circ} \mathrm{C}$ dan kecepatan pengadukan $300 \mathrm{rpm}$ dan $500 \mathrm{rpm}$. Setelah itu sampel dianalisa dengan GC-MS untuk mengetahui kandungan asam palmitatnya dan didapatkan kandungan asam palmitat paling tinggi jika dimasukkan dalam rumus regresi sebagai berikut $y=-0,0333 x^{2}+1,4518 x+67,617$ dengan $R^{2}=0,8431$ dengan kandungan asam palmitat $84,91 \%$.
\end{abstract}

Kata kunci: Asam Palmitat, Fraksinasi, Pelarut Organik, Stearin

\section{ABSTRACT}

Palm oil is the most oil in Indonesia. Palm oil contains two types of products: solid fraction (Stearin) and liquid fraction (Olein). Fatty acids in palm oil are divided into two groups, namely saturated fatty acids and unsaturated fatty acids. This study aims to separate Tripalmitin from the hardness fraction of palm oil by fractionation method with organic solvent. The variables in this study used variation of organic / organic solvent ratio 1:10 (w / v) and $1: 12(\mathrm{w} / \mathrm{v})$ with temperature $2^{\circ} \mathrm{C}, 10^{\circ} \mathrm{C}, 20^{\circ} \mathrm{C}, 30^{\circ} \mathrm{C}, 40^{\circ} \mathrm{C}$ and stirring speed $300 \mathrm{rpm}$ and $500 \mathrm{rpm}$. After that the sample was analyzed with GC-MS to determine the content of palmitic acid and get the highest palmitic acid content if in the regression formula as follows $y$ $=-0.0333 x 2+1.4518 x+67,617$ with $R^{2}=0.8431$ with the content of palmitic acid $84,91 \%$.

Keywords: Fractination, Organic Solvent, Palmitic Acid, Stearin 


\section{PENDAHULUAN}

Kelapa sawit merupakan salah satu tanaman yang sangat banyak dibudidayakan di Indonesia karena memang banyak dibutuhkan untuk industri pangan dan non pangan. Indonesia menempati posisi pertama dalam produksi minyak sawit mentah (CPO) di dunia dan disusul Malaysia. Jika pada tahun 1994 baru terdapat sekita 1,8 juta hektar luas perkebunan kelapa sawit, maka pada tahun 2013 luasnya sudah mencapai 9,0 juta hektar, dan pada tahun 2020 diprediksi mencapai 14 juta hektar (Mulyadi, 2009).

Minyak sawit adalah ester asam lemak dan gliserol yang disebut dengan trigliserida. Minyak sawit berwujud setengah padat pada temperatur ruangan dan memiliki beberapa jenis lemak jenuh antara lain asam laurat $(0.1 \%)$, asam miristat $(1 \%)$, asam stearat $(5 \%)$, dan asam palmitat (44\%). Minyak sawit juga memiliki lemak tak jenuh dalam bentuk asam oleat $(39 \%)$, asam linoleat $(10 \%)$, dan asam alfa linoleat $(0.3 \%)$ (Wikipedia, 2014).

Dalam asam lemak sendiri terdiri dari asam lemak jenuh dan asam lemak tak jenuh. Asam lemak dikatakan asam lemak jenuh apabila terdapat ikatan rangkap begitupun sebaliknya. Pada minyak kelapa sawit, seperti pada minyak nabati umumnya, asam lemak jenuh terdapat pada tempat nomor satu. Formasi yang kerapkali ditemukan adalah palmitatoleat-palmitat dan palmitat-oleat-oleat. Trigliserida yang hanya memiliki radikal asam stearat dinamakan (tri)stearin, hal yang sama dengan radikal palmitat disebut (tri)palmitin, dan radikal oleat (tri)olein. (minyak kelapa sawit, 2014)

Minyak sawit dapat difraksinasi untuk memperoleh dan memisahkan fraksi padat stearin dan fraksi cair olein. Pada penelitian kali ini yaitu ekstraksi tripalmitin dengan fraksi padat minyak sawit, sebenarnya tripalmitin dapat dibuat langsung dengan mengkondensasikan 3 asam palmitat dengan gliserol. Disamping itu dalam penelitian ini digunakan cara ekstraksi karena dengan menggunakan cara ekstraksi diyakini dapat menghasilkan produk tripalmitin yang lebih murni atau dengan mutu yang lebih baik. Pada penelitian ini digunakan juga fraksi padat (stearin) karena memang fraksi padat dari minyak padat sendiri jarang sekali digunakan untuk proses penelitian lebih lanjut dan fraksi padat sendiri lebih memiliki kandungan asam palmitat atau tripalmitin paling banyak dibandingkan produk olahan lanjut dari fraksi cair (olein) dari minyak sawit sendiri.

Salah satu cara sederhana yang akan dilakukan di penelitian ini adalah dengan cara memfraksinasi palm stearin (fraksi padat minyak kelapa sawit) untuk mendapatkan tripalmitin yang tersusun dari tiga asam palmitat dan pada akhirnya diharapkan dapat dikembangkan dan digunakan untuk kebutuhan bahan baku dalam negeri, terutama sebagai bahan baku susu bayi.

\section{METODE}

\section{a. Bahan - Bahan}

Penelitian dilakukan di laboratorium Puspitek serpong LAPTIAB (Lab Teknologi Proses Agroindustri).

Alat yang digunakan dalam penelitian ini adalah Labu leher tiga, Kondensor, Magnetic Stirrer, Statif, Klem, Minichiller, Rotavapor, Vacuum Pump, Timbangan digital, Spatula, Beaker Glass, Gelas ukur, Erlenmeyer, Thermometer, Kertas saring, Cawan petri, cawan porselin, Corong, Botol sampel. Bahan baku yang di pergunakan pada penelitian ini adalah Fraksi padat minyak sawit, pelarut organik, Metanol, $\mathrm{NaOH}$.

\section{b. Proses Fraksinasi}

Bahan baku utama dalam proses fraksinasi ini adalah Fraksi padat dari minyak sawit, maka penelitian ini dilakukan melalui dua tahap yaitu proses fraksinasi, dan transesterifikasi. pertama tahap fraksinasi yaitu bertujuan memisahkan tripalmitin dengan fraksi trigliserida lainnya dengan menggunakan pelarut organik. Timbang fraksi padat minyak sawit dalam timbangan digital sebanyak 40 gr. Masukkan fraksi padat minyak sawit ke dalam labu leher tiga menggunakan spatel. Masukkan pelarut organik sesuai ratio 1:10 dan 1:12 (w/v) lalu masukkan magnetic stirrer ke dalam labu leher tiga. Setelah itu, tutup labu leher tiga agar pelarut organik tidak menguap. Lalu diekstraksi diatas magnetik stirer dengan variasi suhu $2^{\circ} \mathrm{C}$, 
$10^{\circ} \mathrm{C}, \quad 20^{\circ} \mathrm{C}, \quad 30^{\circ} \mathrm{C}$ dan $40^{\circ} \mathrm{C}$ dengan kecepatan pengadukan 500 dan 300 rpm selama 5 jam. Setelah 5 jam, lalu di filtrasi menggunakan vacum pump sebanyak 2 kali saring. Filtrat dalam kertas saring dimasukkan ke dalam erlenmeyer untuk di rotary evaporator pada suhu $60^{\circ} \mathrm{C}$ dengan kecepatan putaran $75 \mathrm{rpm}$ sampai pelarut habis. Hasil yang didapat didiamkan satu hari pada suhu kamar. Keesokkan harinya hasil ditimbang dan dimasukkan kedalam plastik sampel. Hasil yang didapat sebagian diesterifikasi untuk analisa GCMS.

c. Analisa GC/MS

Tahapan selanjutnya untuk memecah rantai karbon Tripalmitin menjadi metil palmitat yaitu dengan mereaksikan Tripalmitin hasil ekstraksi dan metanol (transesterifikasi) dengan katalis $\mathrm{NaOH}$ selama 90 menit. Setelah selesai proses, didiamkan beberapa menit lalu tuangkan kedalam corong pemisah. Tunggu sampai lapisan atas (metil ester) dan lapisan bawah (gliserol) terpisah. Lalu, pisahkan lapisan bawah. Sisakan lapisan atas dalam corong pemisah. Setelah itu masukan larutan $\mathrm{H}_{2} \mathrm{SO}_{4} 10 \%$ sebanyak $5 \mathrm{ml}$ untuk menghilangkan katalis $\mathrm{NaOH}$. Diukur sampai $\mathrm{PH} 2$. Setelah itu dicuci dengan air hangat $\pm 60^{\circ} \mathrm{C}$ untuk menetralkan larutan. Lalu, diukur $\mathrm{PH}$ sampai 7. Pisahkan lapisan atas (metil ester) dengan lapisan bawah (air). Ambil lapisan atas kedalam beaker glass. Masukkan $\mathrm{Na}_{2} \mathrm{SO}_{4}$ kedalam metil ester, lalu diaduk sampai bening untuk menghilangkan air yang tersisa. Setelah itu disaring dengan kertas saring. Masukkan kedalam botol sampel.

Produk yang dihasilkan dari proses esterifikasi dimasukkan kedalam alat GCMS untuk mengetahui kandungan metil palmitat dalam setiap sampel.

\section{HASIL DAN PEMBAHASAN}

\section{A. Hasil proses Fraksinasi}

Proses fraksinasi ini menggunakan 20 sampel yang berbeda variabel suhu, rasio (bahan baku / pelarut organik) dan kecepatan pengadukan. Variabel suhu mengunakan suhu $2^{\circ} \mathrm{C}, 10^{\circ} \mathrm{C}, 20^{\circ} \mathrm{C}, 30^{\circ} \mathrm{C}$, $40^{\circ} \mathrm{C}$. Untuk variasi rasio menggunakan rasio 1:10 dan 1:12 (w/v). Dengan kecepatan pengadukan 300 rpm dan 500 rpm.

Tabel 1. Komposisi setiap sampel

\begin{tabular}{|c|c|c|c|}
\hline $\begin{array}{c}\text { No. } \\
\text { Sampel }\end{array}$ & $\begin{array}{c}\text { Suh } \\
\text { u }\end{array}$ & Rasio & rpm \\
\hline Sampel 1 & 2 & $1: 10$ & 500 \\
\hline Sampel 2 & 2 & $1: 12$ & 500 \\
\hline Sampel 3 & 10 & $1: 10$ & 500 \\
\hline Sampel 4 & 10 & $1: 12$ & 500 \\
\hline Sampel 5 & 20 & $1: 10$ & 500 \\
\hline Sampel 6 & 20 & $1: 12$ & 500 \\
\hline Sampel 7 & 30 & $1: 10$ & 500 \\
\hline Sampel 8 & 30 & $1: 12$ & 500 \\
\hline Sampel 9 & 40 & $1: 10$ & 500 \\
\hline Sampel 10 & 40 & $1: 12$ & 500 \\
\hline Sampel 11 & 2 & $1: 10$ & 300 \\
\hline Sampel 12 & 2 & $1: 12$ & 300 \\
\hline Sampel 13 & 10 & $1: 10$ & 300 \\
\hline Sampel 14 & 10 & $1: 12$ & 300 \\
\hline Sampel 15 & 20 & $1: 10$ & 300 \\
\hline Sampel 16 & 20 & $1: 12$ & 300 \\
\hline Sampel 17 & 30 & $1: 10$ & 300 \\
\hline Sampel 18 & 30 & $1: 12$ & 300 \\
\hline Sampel 19 & 40 & $1: 10$ & 300 \\
\hline Sampel 20 & 40 & $1: 12$ & 300 \\
\hline
\end{tabular}

Tabel 2. Hasil proses fraksinasi

\begin{tabular}{|c|c|c|}
\hline $\begin{array}{c}\text { No. } \\
\text { Sampel }\end{array}$ & $\begin{array}{c}\text { Berat } \\
\text { Hasil } \\
\text { Ekstrak } \\
\text { si (gr) }\end{array}$ & $\begin{array}{c}\text { Rendemen } \\
\text { (\%) }\end{array}$ \\
\hline Sampel 1 & 18,4188 & 46,05 \\
\hline Sampel 2 & 18,5399 & 46,35 \\
\hline Sampel 3 & 14,7712 & 36,93 \\
\hline Sampel 4 & 10,3885 & 25,97 \\
\hline Sampel 5 & 11,2293 & 28,07 \\
\hline Sampel 6 & 10,5269 & 26,32 \\
\hline Sampel 7 & 11,1942 & 27,99 \\
\hline Sampel 8 & 10,1314 & 25,33 \\
\hline Sampel 9 & 18,7612 & 46,90 \\
\hline Sampel 10 & 11,4969 & 28,74 \\
\hline Sampel 11 & 17,2 & 43,00 \\
\hline Sampel 12 & 17,4 & 43,50 \\
\hline Sampel 13 & 16,4 & 41,00 \\
\hline Sampel 14 & 17,8 & 44,50 \\
\hline Sampel 15 & 12,5998 & 31,49 \\
\hline Sampel 16 & 9,8367 & 24,60 \\
\hline Sampel 17 & 20,7006 & 51,75 \\
\hline Sampel 18 & 22,3929 & 55,98 \\
\hline Sampel 19 & 10,6 & 26,50 \\
\hline
\end{tabular}




\begin{tabular}{|l|l|r|}
\hline Sampel 20 & 9,4 & 23,50 \\
\hline
\end{tabular}

\section{B. Proses Transesterifikasi}

Proses transesterifikasi ini untuk memecah rantai karbon. Untuk pengambilan berat sampel awal, sampel dengan hasil transesterifikasi diatas $15 \mathrm{gr}$ diambil sebanyak $10 \mathrm{gr}$. Sedangkan, untuk sampel dengan hasil transesterifikasi dibawah $15 \mathrm{gr}$ diambil sebanyak $5 \mathrm{gr}$. Reaksi Transesterifikasi ini dengan mereaksikan Trigliserida dengan metanol dan menggunakan katalis $\mathrm{NaOH}$ selama 90 menit.

Setelah selesai proses, didiamkan beberapa menit lalu tuangkan kedalam corong pemisah. Tunggu sampai lapisan atas (metil ester) dan lapisan bawah (gliserol) terpisah. Setelah itu masukan larutan $\mathrm{H}_{2} \mathrm{SO}_{4} \quad 10 \%$ sebanyak $5 \mathrm{ml}$. Setelah itu dicuci dengan air hangat $\pm 60^{\circ} \mathrm{C}$. Masukkan $\mathrm{Na}_{2} \mathrm{SO}_{4}$ kedalam metil ester, lalu diaduk sampai bening untuk menghilangkan air yang tersisa. Setelah itu disaring dengan kertas saring.

\section{Hasil Analisa GC-MS}
1. Pengaruh Suhu Terhadap Kandungan Asam Palmitat Dengan Rasio Bahan Baku / Pelarut Organik (w/v) 1:10 Pada Kecepatan Pengadukan 500 rpm

Tabel 3. Hasil Proses Transesterifikasi

\begin{tabular}{|c|c|c|c|c|}
\hline $\begin{array}{c}\text { No. } \\
\text { Sampel }\end{array}$ & $\begin{array}{c}\text { Awa } \\
\text { I (gr) }\end{array}$ & $\begin{array}{c}\text { Met } \\
\text { anol } \\
\text { (gr) }\end{array}$ & $\begin{array}{c}\text { Kata } \\
\text { lis } \\
\text { (gr) }\end{array}$ & $\begin{array}{c}\text { Hasil } \\
\text { (gr) }\end{array}$ \\
\hline Sampel 1 & 10 & 9,6 & 0,2 & 4,5 \\
\hline Sampel 2 & 10 & 9,6 & 0,2 & 1,9 \\
\hline Sampel 3 & 10 & 9,6 & 0,2 & 0,6 \\
\hline Sampel 4 & 5 & 4,8 & 0,1 & 1,2 \\
\hline Sampel 5 & 5 & 4,8 & 0,1 & 1,8 \\
\hline Sampel 6 & 5 & 4,8 & 0,1 & 1,0 \\
\hline Sampel 7 & 5 & 4,8 & 0,1 & 1,8 \\
\hline Sampel 8 & 5 & 4,8 & 0,1 & 1,2 \\
\hline Sampel 9 & 10 & 9,6 & 0,2 & 1,2 \\
\hline Sampel 10 & 5 & 4,8 & 0,1 & 0,8 \\
\hline Sampel 11 & 10 & 9,6 & 0,2 & 2,0 \\
\hline Sampel 12 & 10 & 9,6 & 0,2 & 0,6 \\
\hline Sampel 13 & 10 & 9,6 & 0,2 & 0,8 \\
\hline Sampel 14 & 10 & 9,6 & 0,2 & 2,8 \\
\hline Sampel 15 & 5 & 4,8 & 0,1 & 1,4 \\
\hline Sampel 16 & 5 & 4,8 & 0,1 & 0,6 \\
\hline Sampel 17 & 10 & 9,6 & 0,2 & 0,8 \\
\hline Sampel 18 & 10 & 9,6 & 0,2 & 2,4 \\
\hline Sampel 19 & 5 & 4,8 & 0,1 & 0,3 \\
\hline Sampel 20 & 5 & 4,8 & 0,1 & 1,5 \\
\hline
\end{tabular}

Setelah sampel di transesterifikasi, sampel dilakukan proses analisa menggunakan GC-MS. Sehingga didapatkan data kandungan asam palmitat.

Tabel 4. Kandungan asam palmitat Hasil GC/MS pada rasio 1:10 (w/v) dengan kecepatan pengadukan $500 \mathrm{rpm}$

\begin{tabular}{|c|c|c|c|}
\hline No. Sampel & $\begin{array}{c}\text { Ratio bahan baku / pelarut } \\
\text { organik (w/v) }\end{array}$ & Suhu $\left({ }^{\circ} \mathrm{C}\right)$ & Asam Palmitat (\%) \\
\hline Sampel 1 & $1: 10$ & 2 & 72,27 \\
\hline Sampel 3 & $1: 10$ & 10 & 74,95 \\
\hline Sampel 5 & $1: 10$ & 20 & 84,91 \\
\hline Sampel 7 & $1: 10$ & 30 & 82,54 \\
\hline Sampel 9 & $1: 10$ & 40 & 71,59 \\
\hline
\end{tabular}

Pada rasio bahan baku / pelarut organik (w/v) 1:10 dengan kecepatan pengadukan $500 \mathrm{rpm}$ didapat kandungan asam palmitat paling tinggi yaitu sampel 5 pada suhu $20^{\circ} \mathrm{C}$ dengan kandungan asam palmitat $84,91 \%$ dan yang paling rendah pada suhu $40^{\circ} \mathrm{C}$ dengan kandungan asam palmitat $71,59 \%$. Dari data tersebut didapatkan suhu yang optimum untuk ekstraksi Tripalmitin adalah pada suhu $20^{\circ} \mathrm{C}$. Sesuai pada Tabel 4 rata-rata kandungan asam palmitat pada rasio 1:10 dengan kecepatan pengadukan $500 \mathrm{rpm}$ ini adalah $77,25 \%$. 
Sesuai pada Gambar 1 persamaan yang didapat pada hubungan suhu terhadap kandungan asam palmitat dengan rasio bahan baku / pelarut organik (w/v) 1:10 pada kecepatan $500 \mathrm{rpm}$ adalah sebagai berikut $y=-0,0333 \times 2+$ $1,4518 x+67,617$ dengan $R^{2}=0,8431$ yang mana y sebagai kandungan asam palmitat dan $x$ sebagai suhu ekstraksi.

\section{Pengaruh Suhu Terhadap Kandungan Asam Palmitat Dengan Rasio Bahan Baku I Pelarut Organik (w/v) 1:12 Pada Kecepatan Pengadukan 500 rpm.}

Setelah sampel di transesterifikasi, sampel dilakukan proses analisa menggunakan GC-MS. Sehingga didapatkan data kandungan asam palmitat.

Tabel 5. Hasil kandungan asam palmitat pada rasio 1:12 (w/v) dengan kecepatan pengadukan $500 \mathrm{rpm}$

\begin{tabular}{|c|c|c|c|}
\hline No. Sampel & $\begin{array}{c}\text { Ratio bahan baku / pelarut } \\
\text { organik }(\mathrm{w} / \mathrm{v})\end{array}$ & Suhu $\left({ }^{\circ} \mathrm{C}\right)$ & Asam Palmitat (\%) \\
\hline Sampel 2 & $1: 12$ & 2 & 73,91 \\
\hline Sampel 4 & $1: 12$ & 10 & 80,26 \\
\hline Sampel 6 & $1: 12$ & 20 & 74,52 \\
\hline Sampel 8 & $1: 12$ & 30 & 83,27 \\
\hline Sampel 10 & $1: 12$ & 40 & 81,97 \\
\hline
\end{tabular}

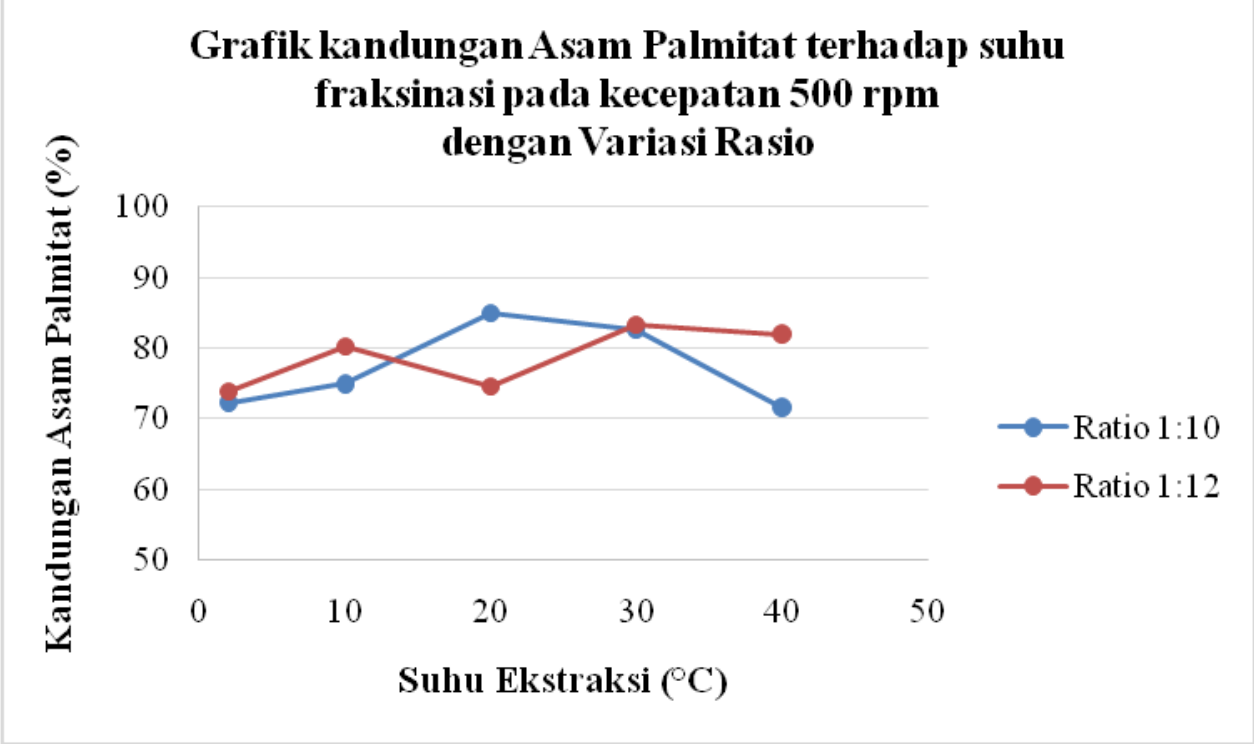

Gambar 1. Grafik kandungan Asam Palmitat terhadap suhu fraksinasi pada kecepatan 500 rpm dengan Variasi Rasio

Pada rasio bahan baku / pelarut organik 1:12 (w/v) dan kecepatan pengadukan $500 \mathrm{rpm}$ ini didapat kandungan asam palmitat paling tinggi yaitu sampel 8 pada suhu $30^{\circ} \mathrm{C}$ dengan kandungan asam palmitat $83,27 \%$ dan yang paling rendah terjadi pada suhu $2^{\circ} \mathrm{C}$ dengan kandungan asam palmitat 73,91\%. Sesuai pada Tabel 4.5. rata-rata kandungan asam palmitat pada rasio $1: 12$ (w/v) dengan kecepatan pengadukan 500 rpm ini adalah $78,79 \%$. Disini terjadi peningkatan rata-rata kandungan asam palmitat, hal ini membuktikan bahwa semakin besar rasio, maka semakin besar pula kandungan asam palmitat yang didapat. 
Sesuai pada gambar 4.2. persamaan yang didapat pada hubungan suhu terhadap kandungan asam palmitat dengan rasio bahan baku / pelarut organik $1: 12(\mathrm{w} / \mathrm{v})$ pada kecepatan pengadukan $500 \mathrm{rpm}$ adalah sebagai berikut $\mathrm{y}=$ $0.0002 x^{4}+0.0206 x^{3}-0.5471 x^{2}+5.1105 x$ +65.717 dengan $R^{2}=1$ dimana y sebagai kandungan asam palmitat dan $\mathrm{x}$ sebagai suhu ekstraksi.

\section{Pengaruh Suhu Terhadap Kandungan Asam Palmitat Dengan Rasio Bahan/Pelarut (w/v) 1:10 Pada Kecepatan Pengadukan 300 rpm.}

Setelah sampel di transesterifikasi, sampel dilakukan proses analisa menggunakan GC-MS. Sehingga didapatkan data kandungan asam palmitat.

Tabel 6. Hasil kandungan asam palmitat pada rasio 1:10 (w/v) dengan kecepatan pengadukan $300 \mathrm{rpm}$

\begin{tabular}{|c|c|c|c|}
\hline No. Sampel & $\begin{array}{c}\text { Ratio bahan baku / pelarut } \\
\text { organik (w/v) }\end{array}$ & Suhu $\left({ }^{\circ} \mathrm{C}\right)$ & Asam Palmitat (\%) \\
\hline Sampel 11 & $1: 10$ & 2 & 62,51 \\
\hline Sampel 13 & $1: 10$ & 10 & 70,76 \\
\hline Sampel 15 & $1: 10$ & 20 & 65,25 \\
\hline Sampel 17 & $1: 10$ & 30 & 67,71 \\
\hline Sampel 19 & $1: 10$ & 40 & 68,39 \\
\hline
\end{tabular}

Pada rasio bahan baku / pelarut organik 1:10 (w/v) dan kecepatan pengadukan $300 \mathrm{rpm}$ didapat kandungan asam palmitat paling tinggi yaitu sampel 13 pada suhu $10^{\circ} \mathrm{C}$ dengan kandungan asam palmitat $70,76 \%$ dan yang paling rendah terjadi pada suhu $2^{\circ} \mathrm{C}$ dengan kandungan asam palmitat $62,51 \%$. Sesuai pada Tabel 6. rata-rata kandungan asam palmitat pada rasio 1:10 dengan kecepatan pengadukan $300 \mathrm{rpm}$ ini adalah $66,92 \%$. Disini terjadi penurunan rata-rata kandungan asam palmitat dari $77,25 \%$ pada kecepatan pengadukan $500 \mathrm{rpm}$ menjadi $66,92 \%$ pada kecepatan $300 \mathrm{rpm}$, hal ini membuktikan bahwa semakin cepat kecepatan pengadukan, maka semakin besar pula kandungan asam palmitat yang didapat.

Sesuai pada Gambar 3. persamaan yang didapat pada hubungan suhu terhadap kandungan asam palmitat dengan rasio bahan/pelarut (w/v) 1:10 pada kecepatan $300 \mathrm{rpm}$ adalah sebagai berikut $y=-0.0002 x^{4}+0.0147 x^{3}-$ $0.4326 x^{2}+4.6076 x+54.91$ dengan $R^{2}=1$ dimana y sebagai kandungan asam palmitat dan $x$ sebagai suhu fraksinasi.

\section{Pengaruh Suhu Terhadap kandungan Asam Palmitat Dengan Rasio Bahan Baku I Pelarut Organik 1:12 (w/v) Pada Kecepatan Pengadukan 300 rpm.}

Setelah sampel di transesterifikasi, sampel dilakukan proses analisa menggunakan GC-MS. Sehingga didapatkan data kandungan asam palmitat.

Tabel 7. Kandungan asam palmitat dengan GC/MS pada rasio 1:12 (w/v) dengan kecepatan pengadukan $300 \mathrm{rpm}$

\begin{tabular}{|c|c|c|c|}
\hline No. Sampel & Ratio bahan/pelarut $(\mathrm{w} / \mathrm{v})$ & Suhu $\left({ }^{\circ} \mathrm{C}\right)$ & Asam Palmitat $(\%)$ \\
\hline Sampel 12 & $1: 12$ & 2 & 62,44 \\
\hline Sampel 14 & $1: 12$ & 10 & 62,46 \\
\hline
\end{tabular}




\begin{tabular}{|l|l|l|l|} 
Sampel 16 & $1: 12$ & 20 & 73,09 \\
\hline Sampel 18 & $1: 12$ & 30 & 57,92 \\
\hline Sampel 20 & $1: 12$ & 40 & 74,87 \\
\hline
\end{tabular}

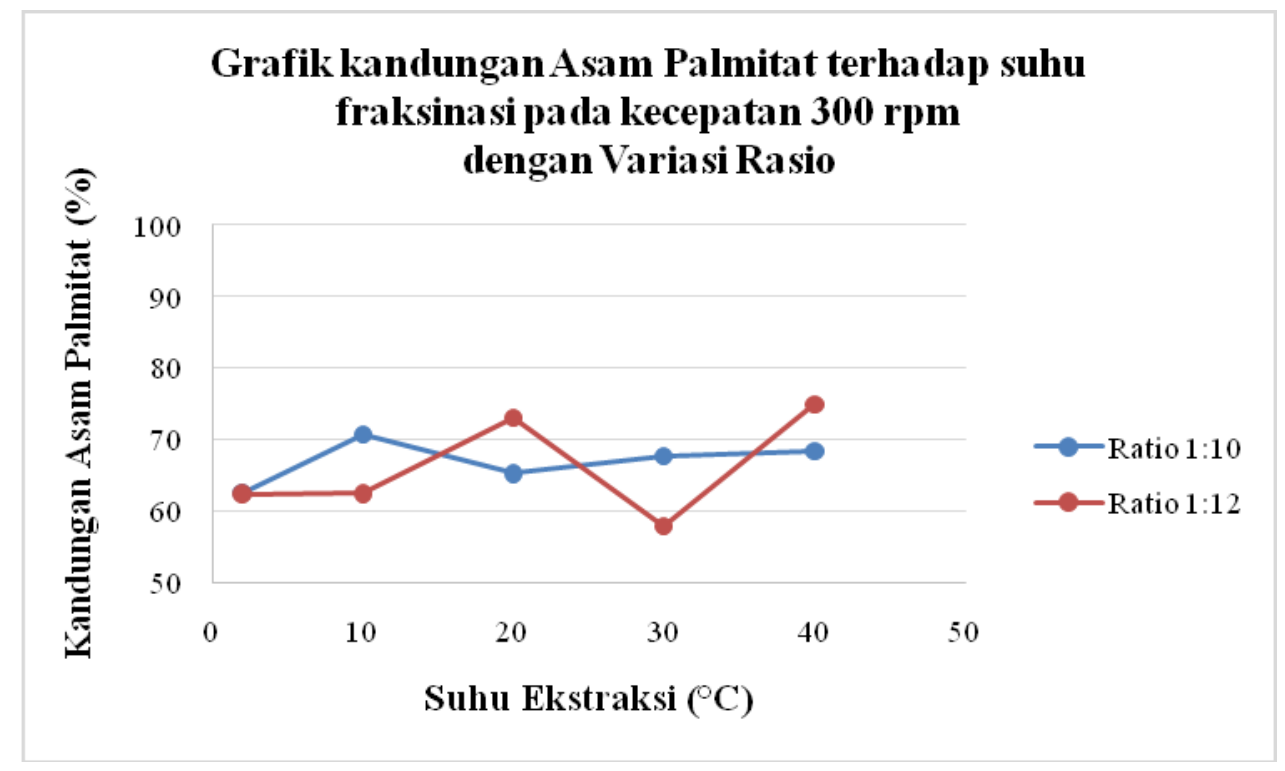

Gambar 2. Grafik kandungan Asam Palmitat terhadap suhu fraksinasi pada kecepatan 300 rpm dengan Variasi Rasio

Pada rasio bahan baku / pelarut organik 1:12 (w/v) dan kecepatan pengadukan $300 \mathrm{rpm}$ ini didapat kandungan asam palmitat paling tinggi yaitu sampel 20 pada suhu $40^{\circ} \mathrm{C}$ dengan kandungan asam palmitat $74,87 \%$ dan yang paling rendah terjadi pada suhu $30^{\circ} \mathrm{C}$ dengan kandungan asam palmitat $57,92 \%$. Sesuai pada Tabel 7. rata-rata kandungan asam palmitat pada rasio 1:10 dengan kecepatan pengadukan 300 rpm ini adalah $66,16 \%$.

Sesuai pada gambar 4. persamaan yang didapat pada hubungan suhu fraksinasi terhadap kandungan asam palmitat dengan rasio bahan baku / pelarut organik 1:12 (w/v) pada kecepatan pengadukan $300 \mathrm{rpm}$ adalah sebagai berikut $y=0.0004 x^{4}-0.0334 x^{3}+0.7991 x^{2}$ $-5.9808 x+71.466$ dengan $R^{2}=1$ dimana $y$ sebagai kandungan asam palmitat dan $x$ sebagai suhu fraksinasi.

\section{SIMPULAN DAN SARAN}

\section{Kesimpulan}

Dari data hasil penelitian mengenai fraksinasi Tripalmitin dari Fraksi Padat
Minyak Sawit menggunakan pelarut organik, maka dapat disimpulkan bahwa memisahkan Tripalmitin dari Fraksi Padat Minyak Sawit dapat dilakukan dengan proses fraksinasi dengan menggunakan pelarut organik. Untuk Pengaruh suhu : Semakin tinggi suhu, maka semakin banyak kandungan Tripalmitin yang didapat. Sedangkan Pengaruh rasio : Semakin besar rasio, maka semakin banyak kandungan Tripalmitin yang didapat. Untuk Pengaruh kecepatan pengadukan, semakin cepat pengadukan maka semakin banyak pula kandungan Tripalmitin yang didapat. Serta Kondisi terbaik untuk mengekstrak Tripalmitin yaitu pada sampel 5 , dengan suhu $20^{\circ} \mathrm{C}$ dan rasio bahan baku / pelarut organik $1: 10(\mathrm{w} / \mathrm{v})$ pada kecepatan pengadukan $500 \mathrm{rpm}$.

\section{Saran}

Untuk penelitian selanjutnya disarankan untuk dilakukannya penelitian fraksinasi Tripalmitin melalui fraksinasi dari fraksi padat minyak sawit dengan variasi waktu fraksinasi dan kecepatan pengadukan lebih ditingkatkan untuk 
meningkatkan kandungan asam palmitat dalam Tripalmitin sebagai bahan baku susu.

\section{DAFTAR PUSTAKA}

Deni Pranowo, M. Muchalal, 2004, Analisis Kandungan Asam Lemak pada Minyak Kedelai dengan Kromatografi Gas-Spektroskopi Massa, Jurusan Kimia, Fakultas MIPA Universitas Gadjah Mada, Yogyakarta.

Endang K., Sutarno., dan Citra Kartika., 2009, Ekstraksi Minyak Biji Mengkudu (Morinda Citrifolia L) pada Variasi Jenis Pelarut, Surakarta: Jurusan Teknik Kimia Fakultas Teknik Universitas Sebelas Maret.

Geoff Talbot, Kevin W. Smith, Fred W. Cain., 2006, Solvent fractionation of palm oil, originally published in Inform, vol 17, no. 5, pages 324-326 and reproduced by permission.

Hamilton, R. I. 1995. Development in Oil and Fats. Chapman and Hall, New York.

Herman, S., \& Khairat, 2004, Kinetika Reaksi Hidrolisis Minyak Sawit dengan Katalisator Asam Klorida, Jurnal Natur Indonesia, 6(2): 118121.

https://id.wikipedia.org/wiki/Aseton, diakses pada tanggal 12 Januari 2016

https://id.wikipedia.org/wiki/Minyak_sawit, diakses pada tanggal 22 Desember 2015

https://en.wikipedia.org/wiki/Tripalmitin, diakses pada tanggal 4 Januari 2016

Hui, Y.H., 1996, Bailey's Industrial Oil and Fat Product: Industrial and Consumer Non edible products from Oil and Fats, vol 5, 5th ed, John Wiley \& Sons, New York.

Pahan, lyung, 2008. Panduan Lengkap Kelapa Sawit Manajemen Agribisnis dari Hulu hingga Hilir. Penebar Swadaya. Jakarta

J.W. Hampson, 1998, Separation of Tripalmitin from Its Hydrolysis Products by Simple Isocratic Reversed Phase High Performance Liquid Chromatography, Wyndmoor Pennsylvania.

M. Andhika Akbar, 2012, Optimasi Ekstraksi Spent Bleaching Earth Dalam Recovery Minyak Sawit, Skripsi: Teknik Kimia Fakultas Teknik Universitas Indonesia, Depok.

Ketaren S., 1986, Pengantar Teknologi Minyak dan Pangan, UI Press, Jakarta.

Krishna P. Candra, 2007, Prinsip-prinsip Ekstraksi Minyak Lemak, PS Teknologi Hasil Pertanian Faperta UNMUL.

Nurhida Pasaribu, 2004, Minyak Buah Kelapa Sawit, Sumatera: Jurusan Kimia Fakultas Matematika Dan IImu Pengetahuan Alam Universitas Sumatera Utara.

Olie, J.J and Tjeng, T.D, 1988 , The Extraction of Palm Oil, Stork Amsterdam.

Pitoyo, 1988, Kemungkinan Ekstraksi Beta-karotena dari Tanab Pemucat Limbah Proses Pemurnian Minyak Kelapa Sawit, Yogyakarta : UGM.

Puguh Setyopratomo, 2012, Jurnal Penelitian Produksi Asam Lemak dari Minyak Kelapa Sawit dengan Proses Hidrolisis, Surabaya: Jurusan Teknik Kimia Fakultas Teknik Universitas Surabaya.

Ralph E. Timms, 2007, Fractionation of palm oil: Current status, future possibilities, European Journal of Lipid Science and Technology.

Reni Antika, 2011, Faktor Jenis Konsentrasi Asam dan Pelarut, Politeknik Negeri Sriwijaya, Sumatera Selatan. 
Ritonga, M, (2004). Pengaruh Bilangan Asam Terhadap Hidrolisa Minyak Kelapa Sawit. Digital Library Universitas Sumatera Utara (USU).

Rondang Tambun, 2002, Proses Pembuatan Asam Lemak Secara Langsung dari Buah Kelapa Sawit, Sumatera: Jurusan Teknik Kimia, Fakultas Teknik Universitas Sumatera Utara.

TY Hendrawati, 2015, Aloe vera powder properties produced from aloe chinenis baker, Pontianak, Indonesia, Journal of Engineering Science and Technology Special Issue on SOMCHE 2014 \& RSCE 2014 Conference, January (2015) 47-59 (c) School of Engineering, Taylor's University 